\title{
THE EFFECTS OF SKILL-BASED EXERCISES AND A SMALL-SIDED GAMES PROGRAM ON THE MOTOR SKILLS OF ELEMENTARY SCHOOL STUDENTS
}

\author{
Darko Stojanović ${ }^{1}$, Zoran Momčilović ${ }^{2}$, Tijana Stojanović ${ }^{3}$, Toplica Stojanović ${ }^{4}$ \\ ${ }^{1}$ Faculty of Sports, University Union - Nikola Tesla, Belgrade \\ ${ }^{2}$ Teacher Training Faculty, University of Niš, Vranje \\ ${ }^{3}$ Synchronized swimming club Niš, Niš \\ ${ }^{4}$ The Faculty of Sports and Physical Education, University of Priština - Kosovska Mitrovica, Leposavić
}

\begin{abstract}
.
The purpose of this experimental study was to determine the effects of a skill-based exercise program on the motor skills of a group of elementary school students. The study was conducted on 90 participants, with an average age of 13 , randomly divided into two groups: an experimental [ $\mathrm{n}=39$ (19 girls and 20 boys)] and a control group [ $\mathrm{n}=51$ (24 girls and 27 boys)]. The motor skills were tested at the initial and final measurements. Motor skills were evaluated by 3 flexibility tests, 4 force and strength tests, 4 speed, acceleration and agility tests, and 1 test for assessing cardiorespiratory fitness. After conducting the 16-week program of skill-based exercises and small-sided games related to volleyball, all the parameters of motor skills statistically significantly increased in the experimental group (except for speed among the boys). In the experimental period, the control group did not notice any significant changes in the parameters of the motor skills. The results of this study showed that there were no significant differences in the impact of the two programs on motor skills at the multivariate level but that at the univariate level it was noted that the experimental group of participants following the experimental program had better results compared to the control group of participants in terms of speed and agility tests, for both genders, as well as force and strength among the girls, and cardiorespiratory fitness among the boys. The obtained results indicate that the program of skill-based exercises and small-sided games related to volleyball is suitable for the development of the flexibility, force and strength, and agility of elementary school students.
\end{abstract}

Key words: motor skills, skill-based exercise, small-sided games, physical education, students.

\section{Introduction}

The physical education curriculum plays a significant role in the education of an individual with the aim of using adequate physical activities to contribute to the optimum development of an individual, their growth, motor skills development, and psycho-social characteristics (Hardman, 2007). The harmonic motor skills development of the students creates realistic predispositions to successful completion of other tasks and objectives defined by the school curriculum, which includes the adoption of the content of sports and technique education, in accordance with the age and gender of the students. Based on previous studies on the nature and quality of the physical education curriculum (Todorovski, 1994; Sallis et al., 1997; Stojanović, 1998; Branković, 2001; Milenković, 2002; Dragić, 2003; Koutedakis \& Bouziotas, 2003; Jurg et al., 2006; Stamatović \& Šekeljić, 2006), we could conclude that it is not only insufficiently oriented towards systematic and versatile physical 
exercise, but that it lacks the necessary intensity which could provide stimuli that would improve the physical development and the motor skills of school children (Pate et al., 2006). The question of intensification of physical education classes is more and more urgent, since practice has shown that in the physical education curriculum, neither weekly class load, nor the applied content and workload within regular and elective classes, can fully achieve the defined goals and objectives. The method used to determine modality and workload volume during classes and distribution of the workload have not been studied to a satisfactory extent, since it represents a very complex process, and becomes an inexhaustible source for further study and the design of more and more precise solutions (Pate et al., 2006).

Skill-based exercises are very similar in structure, intensity and duration to the movements of volleyball players during a match (Grgantov, 2003). The similarity between training and competition exercises provides desirable stimuli for the muscles that are important in specific movements in the competition, according to Trajković (2015). The use of skill-based exercises allows the simulation of collective sports movement patterns, with an environment in which the student has to exercise actively under pressure and high intensity (Gabbet, 2002). Skill-based exercises are aimed at faster adoption of a technique (or set of techniques) as a goal, and then the nature of the exercise or game is manipulated to achieve the desired workload intensity.

The small-sided games "mini-volleyball" is designed to simplify the rules by reducing the size of the playing court, changing the number of players and the team and allowing students to make more frequent contact with the ball in order to contribute to the greater intensification of the game and faster and easier adoption of volleyball techniques (Marelić et al., 2000).

The main aim of this research is to determine the effects of the experimental model of skill-based exercises and small sided games related to volleyball, which were conducted during elective physical education classes during one semester, on the transformation of motor skills of the experimental group of participants during the experimental period. The additional aim of this research was to determine the effects of a regular physical education curriculum on the motor skills development of the control group of participants during the same period.

\section{Materials and Methods}

\section{The sample of participants}

The sample for this study comprised 7th grade students of Duško Radović Elementary School in Niš, aged $13 \pm 6$ months. The sample included each student who voluntarily agreed to participate in the study, by following a complete program of testing and physical exercise, with the consent of the parents. The additional condition was that the students should not be exempted from physical education classes and must be clinically healthy on the testing days. For the final processing, only the results of the participants who participated in both measurements (initial and final) and had not more than two absences per month were included. The participant were divided into two groups:

1. An experimental group $(\mathrm{n}=39)$, consisted of 19 girls $(\mathrm{BH}: 160.75 \mathrm{~cm}$; BM: 55.32 $\mathrm{kg}$ ) and 20 boys (BH: $164.28 \mathrm{~cm}$; BM: $56.44 \mathrm{~kg}$ ) and

2. A control group $(n=51)$, consisted of 24 girls $(B H: 159.10 \mathrm{~cm} ; B M: 48.04 \mathrm{~kg})$ and 27 boys (BH: $166.30 \mathrm{~cm}$; BM: $56.76 \mathrm{~kg}$ ). 


\section{Instruments and procedure}

Instruments for anthropometric characteristics assessment included:

1. Body height - $\mathrm{BH}(\mathrm{cm})$

2. Body mass - BM $(k g)$

Instruments for motor skills assessment included:

- Flexibility tests

- Straight leg raise- SLR $\left(^{\circ}\right)$

- Trunk extension - EKST $\left(^{\circ}\right)$

- Sit and reach-FLEX $(\mathrm{cm})$

- Muscle force and explosive strength tests

- Forearm flexion- FFL $(N)$

- Isometric mid-thigh pull - IMTP $(N)$

- Squat jump- SJ ( $\mathrm{cm})$

- Countermovement jump- CMJ (cm)

- Speed and acceleration test

- Sprint 30m with split time at 5m and 10m distance - 30M, 5M, 10M (sec)

- Agility tests

- T- test - TT ( sec)

- Hexagon Agility Test - HEX (sec)

- Japantest - JAPT (sec)

- A cardiorespiratory fitness test

- Shuttle run - 20m "Beep test " - $\mathrm{VO}_{2 \max }(\mathrm{ml} / \mathrm{min} / \mathrm{kg})$.

Body height was measured using a Martin anthropometer GPM 101 (GPM GmbH Switzerland). Body weight was measured using an OMRON BF511 electronic scale (Omron, Japan). A wall goniometer was used in the flexibility tests, as was as a wooden box for the sit and reach test. For the evaluation of force and strength, bicep flexion and trunk extension were tested. Muscle potential was measured under isometric conditions. The Japanese digital force gauge IMADA Z2H-1100 with WinWedge 3.4 software, TAL (Technologies, Philadelphia, PA, USA) was used for force estimation. To assess the explosive strength of the lower limbs (SJ, CMJ), an optical system for measuring vertical jump height OPTOJUMP (Microgate, Italy) was used. For the speed and agility tests, an electronic time-measuring device with photocells, Wireless Training Timer SEM Witty (Microgate, Italy), was used. The "beep test" was taken from the Eurofit battery, described by Adams et al. (1988).

The control group had 3 classes per week - regular physical education classes (two classes) and an elective physical education class (volleyball - one class) according to the curriculum of the Serbian Ministry of Education (Službeni glasnik RS - Prosvetni glasnik, 2006).

The experimental group also had 3 classes per week - regular physical education classes (two classes) according to the curriculum of the Serbian Ministry of Education and an elective physical education class (volleyball - one class) according to the experimental program of skill-based exercises and small-sided games.

The participants of the experimental group carried out the experimental program of skill-based exercises and small-sided games during elective physical education class with a four-part class structure, which included a specific volleyball warm-up for 3-5 minutes with high intensity activities in the function of physically introducing the students to the upcoming activities, muscle-strengthening and mobility increase exercises, and in the main part of the class, high-intensity skill-based exercises and small-sided games 2 on 2, 3 on 3 and 4 on 4 (mini-volleyball). 


\section{Statistical analysis}

Kolmogorov-Smirnov test was applied to analyze the result distribution for the initial and final measurements for both groups. To determine the differences between the initial and final measurements of the participants, a univariate analysis of variance for repeated measures (ANOVA) was applied. The effect size was calculated using the partial eta squared $\left(\eta_{\mathrm{p}}^{2}\right)$, according to Keppel (1991). Effect size (ES) values are classified according to Ferguson (2009) as: no effects if $0 \leq \eta^{2}<0.05$; small effect (SE) if $0.05 \leq \eta^{2}<0.26$; moderate effect (ME) if $0.26 \leq \eta_{p}^{2}<0.64$; and a large effect (LE) if $\eta_{p}^{2} \geq 0.64$. Multivariate and univariate analysis of covariance (MANCOVA/ANCOVA) were used to determine the effects of the experimental program. Statistical significance was determined at $\mathrm{p} \leq 0.05$. The data were processed using the statistical package STATISTICA 10.0 for Windows (StatSoft, Inc., Tulsa).

\section{Results}

The obtained results of the Kolmogorov-Smirnov test on the initial and final measurement of motor skills of the girls in experimental group (Table 1) and control group (Table 2), confirmed the assumption of optimal statistical characteristics of all the applied variables and their normal distribution, which is the assumption for all the other parametric statistical analyses. Among the boys, the Kolmogorov-Smirnov test confirmed the assumption of the normal distribution of the results in all the applied variables on the initial and final measurement of the motor skills of the boys in the experimental group (Table 3) and the control group (Table 4).

Table 1. Differences between initial and final measurements for the experimental group of girls

\begin{tabular}{|c|c|c|c|c|c|c|c|c|}
\hline \multirow{2}{*}{ Variable } & \multicolumn{2}{|c|}{ Mean } & \multicolumn{2}{|c|}{ Std. Dev. } & \multicolumn{2}{|c|}{ K-S (d) } & \multirow{2}{*}{$\mathrm{F}(1 ; 18)$} & \multirow{2}{*}{ ES } \\
\hline & I & $\mathrm{F}$ & I & $\mathrm{F}$ & I & $\mathrm{F}$ & & \\
\hline $\operatorname{SLR}\left({ }^{\circ}\right)$ & 90.84 & $101.74 *$ & 12.62 & 16.61 & 0.18 & 0.11 & 14.14 & $0.44^{\mathrm{ME}}$ \\
\hline $\operatorname{EKST}\left(^{\circ}\right)$ & 17.53 & $19.95 *$ & 4.88 & 5.38 & 0.17 & 0.18 & 9.70 & $0.35^{\mathrm{ME}}$ \\
\hline FLEX $(\mathrm{cm})$ & 25.04 & $27.48 *$ & 6.94 & 5.09 & 0.19 & 0.12 & 6.28 & $0.26^{\mathrm{ME}}$ \\
\hline FFL $(N)$ & 180.32 & $198.05 *$ & 35.88 & 39.97 & 0.17 & 0.15 & 13.66 & $0.43^{\mathrm{ME}}$ \\
\hline $\operatorname{IMTP}(N)$ & 615.00 & $676.00 *$ & 161.20 & 157.88 & 0.14 & 0.12 & 38.56 & $0.68^{\mathrm{LE}}$ \\
\hline $\mathrm{SJ}(\mathrm{cm})$ & 18.17 & 20.11* & 3.63 & 4.16 & 0.15 & 0.08 & 14.50 & $0.45^{\mathrm{ME}}$ \\
\hline $\mathrm{CMJ}(\mathrm{cm})$ & 20.15 & $22.24 *$ & 4.04 & 4.48 & 0.13 & 0.13 & 14.29 & $0.44^{\mathrm{ME}}$ \\
\hline $5 \mathrm{M}(s)$ & 1.46 & $1.31 *$ & 0.11 & 0.12 & 0.13 & 0.10 & 31.13 & $0.63^{\mathrm{ME}}$ \\
\hline $10 \mathrm{M}(s)$ & 2.44 & $2.20 *$ & 0.16 & 0.18 & 0.11 & 0.12 & 40.58 & $0.69^{\mathrm{LE}}$ \\
\hline $30 \mathrm{M}(s)$ & 6.20 & $5.93 *$ & 0.62 & 0.53 & 0.16 & 0.19 & 27.69 & $0.61^{\mathrm{ME}}$ \\
\hline $\mathrm{TT}(s)$ & 14.83 & $13.48 *$ & 0.86 & 1.13 & 0.16 & 0.14 & 38.81 & $0.68^{\mathrm{LE}}$ \\
\hline $\operatorname{HEX}(s)$ & 15.26 & 13.66* & 1.78 & 1.17 & 0.14 & 0.16 & 23.80 & $0.57^{\mathrm{ME}}$ \\
\hline JAPT $(s)$ & 11.51 & $10.58 *$ & 1.58 & 1.14 & 0.13 & 0.11 & 27.53 & $0.60^{\mathrm{ME}}$ \\
\hline $\mathrm{VO}_{2 \max }(\mathrm{ml} / \mathrm{min} / \mathrm{kg})$ & 29.20 & 29.60* & 5.96 & 5.89 & 0.14 & 0.15 & 24.82 & $0.58^{\mathrm{ME}}$ \\
\hline
\end{tabular}

Legend: Mean -arithmetic means; Std.Dev. -standard deviation; * - significant at the $\mathrm{p} \leq 0.05$ level; I - initial measurement; F - final measurement; K-S (d) -significance of the Kolmogorov-Smirnov coefficient; F - F test value; ES - Effect Size

Based on the results of the descriptive statistical analysis, the assumption of normal distribution of the results in all the groups was confirmed, and thus further analyses were made possible by the parametric statistical method "analysis of variance ANOVA repeated measures" to determine the differences between the initial and final measurements 
as well as the "analysis of covariance MANCOVA/ANCOVA" to determine the effects of the experimental program.

Inspection of the results of the univariate analysis of the differences between the initial and final measurements of the experimental group of girls (Table 1) reveals that all the variables of motor skills have statistically significantly better results on the final measurement compared to the initial measurement. Differences between the measurements with a large effect are manifested in the variables TT $(\mathrm{F}=38.81$; $\mathrm{ES}=0.68)$, IMTP $(\mathrm{F}=$ 38.56; $\mathrm{ES}=0.68)$ and $10 \mathrm{M}(\mathrm{F}=40.58 ; \mathrm{ES}=0.69)$, while the differences with moderate effects are observed in the remaining variables.

The results of univariate analysis of the differences between the initial and final measurements of the control group of girls (Table 2) indicate that there were no statistically significant differences in any of the studied variables of motor skills.

Table 2. Differences between initial and final measurements for the control group of girls

\begin{tabular}{|c|c|c|c|c|c|c|c|c|}
\hline \multirow{2}{*}{ Variable } & \multicolumn{2}{|c|}{ Mean } & \multicolumn{2}{|c|}{ Std. Dev. } & \multicolumn{2}{|c|}{ K-S (d) } & \multirow{2}{*}{$F(1 ; 23)$} & \multirow{2}{*}{ ES } \\
\hline & I & $\mathrm{F}$ & I & $\mathrm{F}$ & I & $\mathrm{F}$ & & \\
\hline$\overline{\operatorname{SLR}\left({ }^{\circ}\right)}$ & 86.96 & 88.04 & 17.09 & 18.45 & 0.15 & 0.10 & 0.30 & $0.01^{\mathrm{NE}}$ \\
\hline $\operatorname{EKST}\left({ }^{\circ}\right)$ & 18.00 & 18.42 & 6.94 & 6.34 & 0.13 & 0.17 & 1.60 & $0.07^{\mathrm{SE}}$ \\
\hline FLEX $(\mathrm{cm})$ & 21.05 & 22.22 & 6.98 & 6.72 & 0.17 & 0.09 & 2.78 & $0.11^{\mathrm{SE}}$ \\
\hline FFL $(N)$ & 174.63 & 161.71 & 41.05 & 45.14 & 0.11 & 0.12 & 4.17 & $0.15^{\mathrm{SE}}$ \\
\hline $\operatorname{IMTP}(N)$ & 544.92 & 537.96 & 179.92 & 179.30 & 0.10 & 0.15 & 0.06 & $0.00^{\mathrm{NE}}$ \\
\hline $\mathrm{SJ}(\mathrm{cm})$ & 19.68 & 19.64 & 3.15 & 2.94 & 0.15 & 0.13 & 0.01 & $0.00^{\mathrm{NE}}$ \\
\hline CMJ $(\mathrm{cm})$ & 20.93 & 20.97 & 2.93 & 3.55 & 0.11 & 0.11 & 0.00 & $0.00^{\mathrm{NE}}$ \\
\hline $5 \mathrm{M}(s)$ & 1.33 & 1.32 & 0.16 & 0.13 & 0.15 & 0.15 & 0.04 & $0.00^{\mathrm{NE}}$ \\
\hline $10 \mathrm{M}(s)$ & 2.23 & 2.22 & 0.23 & 0.16 & 0.13 & 0.10 & 0.19 & $0.01^{\mathrm{NE}}$ \\
\hline $30 \mathrm{M}(s)$ & 5.99 & 5.92 & 0.60 & 0.40 & 0.17 & 0.09 & 0.34 & $0.01^{\mathrm{NE}}$ \\
\hline $\mathrm{TT}(s)$ & 14.78 & 14.81 & 2.07 & 1.86 & 0.13 & 0.18 & 0.03 & $0.00^{\mathrm{NE}}$ \\
\hline $\operatorname{HEX}(s)$ & 16.75 & 16.67 & 3.32 & 3.18 & 0.15 & 0.13 & 0.02 & $0.00^{\mathrm{NE}}$ \\
\hline JAPT $(s)$ & 11.58 & 11.38 & 1.51 & 1.08 & 0.09 & 0.11 & 0.60 & $0.03^{\mathrm{NE}}$ \\
\hline $\mathrm{VO}_{2 \max }(\mathrm{ml} / \mathrm{min} / \mathrm{kg})$ & 25.38 & 25.28 & 4.72 & 4.59 & 0.20 & 0.19 & 0.85 & $0.04^{\mathrm{NE}}$ \\
\hline
\end{tabular}

Legend: Mean -arithmetic means; Std.Dev. -standard deviation; * - significant at the $\mathrm{p} \leq 0.05$ level;

I - initial measurement; F - final measurement; K-S (d) -significance of the Kolmogorov-Smirnov coefficient; F - F test value; ES - Effect Size.

In the results of the univariate analysis of the differences between the initial and final measurements of the experimental group of boys (Table 3), it is observed that all the applied motor skills variables have better results at the numerical level at the final measurement, while a statistically significant difference was observed in ten variables. A significant difference between the measurements with a highest but still moderate effect was manifested in the test - HEX $(\mathrm{F}=17.39$; $\mathrm{ES}=0.48)$, TT $(\mathrm{F}=17.09 ; \mathrm{ES}=0.47)$, and a difference with a small effect was observed for the test $-\mathrm{SLR}(\mathrm{F}=5.50 ; \mathrm{ES}=0.22)$.

There were no statistically significant differences in the results of the control group of boys (Table 4) for any of the studied variables of motor skills.

A multivariate analysis of covariance of the applied motor skills variables between the experimental and control group of girls at the final measurement with partialization and neutralization of the recorded differences at the initial measurement is shown in Table 5. After analysis it can be stated that no statistically significant difference among the groups at the required level of $\mathrm{Q}<.05$ was found. It is evident that the experimental program of skillbased exercises and small-sided games at the multivariate level had no greater effect on motor skills than the school physical education program. 
Table 3. Differences between initial and final measurements for the experimental group of boys

\begin{tabular}{|c|c|c|c|c|c|c|c|c|}
\hline \multirow{2}{*}{ Variable } & \multicolumn{2}{|c|}{ Mean } & \multicolumn{2}{|c|}{ Std. Dev. } & \multicolumn{2}{|c|}{$\mathrm{K}-\mathrm{S}(\mathrm{d})$} & \multirow{2}{*}{$F(1 ; 19)$} & \multirow{2}{*}{ ES } \\
\hline & I & $\mathrm{F}$ & I & $F$ & $\mathrm{I}$ & $\mathrm{F}$ & & \\
\hline $\operatorname{SLR}\left({ }^{\circ}\right)$ & 79.60 & 85.35* & 13.34 & 11.61 & 0.11 & 0.19 & 5.50 & $0.22^{\mathrm{SE}}$ \\
\hline $\operatorname{EKST}\left({ }^{\circ}\right)$ & 18.70 & 21.55 & 7.00 & 6.99 & 0.08 & 0.14 & 1.83 & $0.09^{\mathrm{SE}}$ \\
\hline FLEX $(\mathrm{cm})$ & 14.41 & $16.60 \%$ & 7.17 & 7.30 & 0.08 & 0.17 & 6.14 & $0.24^{\mathrm{SE}}$ \\
\hline FFL $(N)$ & 203.90 & 215.70 & 53.35 & 49.49 & 0.15 & 0.13 & 2.10 & $0.10^{\mathrm{SE}}$ \\
\hline $\operatorname{IMTP}(N)$ & 763.10 & 826.35* & 139.84 & 141.17 & 0.15 & 0.13 & 7.07 & $0.27^{\mathrm{ME}}$ \\
\hline $\mathrm{SJ}(\mathrm{cm})$ & 21.02 & 22.89* & 5.38 & 4.72 & 0.15 & 0.12 & 9.11 & $0.32^{\mathrm{ME}}$ \\
\hline $\mathrm{CMJ}(\mathrm{cm})$ & 22.22 & $24.40 *$ & 4.67 & 4.58 & 0.19 & 0.07 & 14.20 & $0.43^{\mathrm{ME}}$ \\
\hline $5 \mathrm{M}(s)$ & 1.31 & 1.28 & 0.11 & 0.14 & 0.14 & 0.23 & 3.93 & $0.17^{\mathrm{SE}}$ \\
\hline $10 \mathrm{M}(s)$ & 2.19 & 2.13* & 0.17 & 0.19 & 0.15 & 0.20 & 9.62 & $0.34^{\mathrm{ME}}$ \\
\hline $30 \mathrm{M}(s)$ & 5.68 & 5.58 & 0.45 & 0.54 & 0.14 & 0.18 & 1.90 & $0.09^{\mathrm{SE}}$ \\
\hline $\mathrm{TT}(s)$ & 14.17 & $12.80 *$ & 1.52 & 1.07 & 0.11 & 0.13 & 17.09 & $0.47^{\mathrm{ME}}$ \\
\hline $\operatorname{HEX}(s)$ & 16.00 & $14.22 *$ & 2.34 & 1.87 & 0.12 & 0.16 & 17.39 & $0.48^{\mathrm{ME}}$ \\
\hline JAPT $(s)$ & 10.81 & $10.08 *$ & 0.99 & 1.29 & 0.12 & 0.12 & 13.19 & $0.41^{\mathrm{ME}}$ \\
\hline $\mathrm{VO}_{2 \max }(\mathrm{ml} / \mathrm{min} / \mathrm{kg})$ & 31.97 & 32.54* & 7.00 & 6.57 & 0.16 & 0.14 & 14.54 & $0.43^{\mathrm{ME}}$ \\
\hline
\end{tabular}

Legend: Mean -arithmetic means; Std.Dev. -standard deviation; * - significant at the $\mathrm{p} \leq 0.05$ level; I - initial measurement; F - final measurement; K-S (d) -significance of the Kolmogorov-Smirnov coefficient; F - F test value; ES - Effect Size

Table 4. Differences between initial and final measurements for the control group of boys

\begin{tabular}{|c|c|c|c|c|c|c|c|c|}
\hline \multirow{2}{*}{ Variable } & \multicolumn{2}{|c|}{ Mean } & \multicolumn{2}{|c|}{ Std. Dev. } & \multicolumn{2}{|c|}{ K-S (d) } & \multirow{2}{*}{$F(1 ; 26)$} & \multirow{2}{*}{ ES } \\
\hline & I & $\mathrm{F}$ & I & $\mathrm{F}$ & I & $\mathrm{F}$ & & \\
\hline$\overline{\operatorname{SLR}\left({ }^{\circ}\right)}$ & 86.85 & 87.30 & 15.44 & 12.65 & 0.10 & 0.10 & 0.04 & $0.00^{\mathrm{NE}}$ \\
\hline $\operatorname{EKST}\left({ }^{\circ}\right)$ & 17.67 & 18.48 & 9.90 & 10.49 & 0.20 & 0.18 & 0.17 & $0.01^{\mathrm{NE}}$ \\
\hline FLEX $(\mathrm{cm})$ & 15.46 & 16.03 & 6.43 & 5.88 & 0.10 & 0.10 & 3.22 & $0.11^{\mathrm{SE}}$ \\
\hline FFL $(N)$ & 250.93 & 252.74 & 61.66 & 75.10 & 0.11 & 0.13 & 0.07 & $0.00^{\mathrm{NE}}$ \\
\hline $\operatorname{IMTP}(N)$ & 878.96 & 903.11 & 193.51 & 209.34 & 0.18 & 0.10 & 1.57 & $0.06^{\mathrm{SE}}$ \\
\hline $\mathrm{SJ}(\mathrm{cm})$ & 23.94 & 24.15 & 4.11 & 4.55 & 0.12 & 0.15 & 0.10 & $0.00^{\mathrm{NE}}$ \\
\hline $\mathrm{CMJ}(\mathrm{cm})$ & 25.38 & 25.66 & 4.39 & 4.12 & 0.09 & 0.07 & 0.26 & $0.01^{\mathrm{NE}}$ \\
\hline $5 \mathrm{M}(s)$ & 1.27 & 1.26 & 0.14 & 0.14 & 0.11 & 0.12 & 0.29 & $0.01^{\mathrm{NE}}$ \\
\hline $10 \mathrm{M}(s)$ & 2.13 & 2.10 & 0.19 & 0.16 & 0.17 & 0.13 & 0.80 & $0.03^{\mathrm{NE}}$ \\
\hline $30 \mathrm{M}(s)$ & 5.38 & 5.36 & 0.40 & 0.43 & 0.12 & 0.11 & 0.31 & $0.01^{\mathrm{NE}}$ \\
\hline $\mathrm{TT}(s)$ & 13.09 & 12.86 & 1.81 & 1.30 & 0.14 & 0.15 & 0.89 & $0.03^{\mathrm{NE}}$ \\
\hline $\operatorname{HEX}(s)$ & 16.87 & 16.45 & 3.10 & 2.82 & 0.08 & 0.13 & 0.62 & $0.02^{\mathrm{NE}}$ \\
\hline JAPT $(s)$ & 9.74 & 9.55 & 1.03 & 0.81 & 0.14 & 0.17 & 3.03 & $0.10^{\mathrm{SE}}$ \\
\hline $\mathrm{VO}_{2 \max }(\mathrm{ml} / \mathrm{min} / \mathrm{kg})$ & 31.93 & 31.80 & 6.50 & 6.35 & 0.17 & 0.13 & 1.45 & $0.05^{\mathrm{SE}}$ \\
\hline
\end{tabular}

Legend: Mean -arithmetic means; Std.Dev. -standard deviation; * - significant at the $p \leq 0.05$ level; I - initial measurement; F - final measurement; K-S (d) -significance of the Kolmogorov-Smirnov coefficient; F - F test value; ES - Effect Size

At the univariate level (Table 5), a statistically significant difference was observed in flexibility (SLR: $\mathrm{F}=8.95, \mathrm{p}=0.006$ ), force and strength (FFL: $\mathrm{F}=11.88, \mathrm{p}=0.002 ; \mathrm{SJ}: \mathrm{F}$ $=5.44, \mathrm{p}=0.027$ and CMJ: $\mathrm{F}=4.29, \mathrm{p}=0.048)$, as well as in agility (SLR: $\mathrm{F}=8.95, \mathrm{p}=$ 0.006 ), where the experimental group of girls achieved better results. The other variables did not show a statistically significant difference between the groups, but it is evident that in all the motor skills tests, the experimental group of girls achieved greater progress than the control group of girls. 
Table 5. Differences between the effects of two programs on motor skills (MANCOVA/ANCOVA) - girls

\begin{tabular}{|c|c|c|c|c|}
\hline Variable & $\begin{array}{c}\text { Adj. Mean } \\
\text { EKS }\end{array}$ & $\begin{array}{c}\text { Adj. Mean } \\
\text { KON }\end{array}$ & $\mathrm{F}^{2}(1 ; 27)$ & $\mathrm{p}$ \\
\hline $\operatorname{SLR}\left({ }^{\circ}\right)$ & 101.41 & 88.37 & 8.95 & $0.006 *$ \\
\hline $\operatorname{EKST}\left({ }^{\circ}\right)$ & 20.00 & 18.36 & 2.90 & 0.100 \\
\hline FLEX $(\mathrm{cm})$ & 26.41 & 23.29 & 4.08 & 0.053 \\
\hline FFL (N) & 197.54 & 162.22 & 11.88 & 0.002* \\
\hline IMTP (N) & 637.56 & 576.40 & 2.66 & 0.115 \\
\hline $\mathrm{SJ}(\mathrm{cm})$ & 20.82 & 18.92 & 5.44 & $0.027 *$ \\
\hline CMJ $(\mathrm{cm})$ & 22.79 & 20.42 & 4.29 & 0.048* \\
\hline $5 \mathrm{M}(\mathrm{s})$ & 1.31 & 1.32 & 0.03 & 0.865 \\
\hline $10 \mathrm{M}(\mathrm{s})$ & 2.21 & 2.21 & 0.01 & 0.942 \\
\hline 30M (s) & 5.97 & 5.88 & 0.41 & 0.529 \\
\hline TT (s) & 13.79 & 14.50 & 2.62 & 0.117 \\
\hline HEX (s) & 14.53 & 15.80 & 2.98 & 0.096 \\
\hline JAPT (s) & 10.61 & 11.35 & 5.37 & $0.028 *$ \\
\hline $\mathrm{VO}_{2 \max }(\mathrm{ml} / \mathrm{min} / \mathrm{kg})$ & 27.58 & 27.30 & 2.10 & 0.159 \\
\hline Wilks Lambda & $\mathrm{F}^{1}$ & Effect - df & Error - df & $\mathbf{Q}$ \\
\hline 0.359 & 1.79 & 14 & 14 & 0.144 \\
\hline
\end{tabular}

Legend: Adjusted means - adjusted values of the arithmetic means; $\mathrm{F}^{2}$ - value of the F-test coefficient; * - statistical significance; Wilks lambda - value of the Wilk's test coefficient for group centroid equality; $\mathrm{F}^{1}$ - value of the F-test coefficient for the significance of Wilk' lambda; Effect df; Error df - degrees of freedom; $\mathrm{Q}$ - centroid difference significance.

Table 6. Differences between the effects of two programs on motor skills (MANCOVA/ANCOVA) - boys

\begin{tabular}{|c|c|c|c|c|}
\hline Variable & $\begin{array}{c}\text { Adj. Mean } \\
\text { EKS }\end{array}$ & $\begin{array}{c}\text { Adj. Mean } \\
\text { KON }\end{array}$ & $\mathrm{F}^{2}(1 ; 31)$ & $\mathrm{p}$ \\
\hline $\operatorname{SLR}\left({ }^{\circ}\right)$ & 86.58 & 86.06 & 0.02 & 0.885 \\
\hline $\operatorname{EKST}\left({ }^{\circ}\right)$ & 19.93 & 20.10 & 0.00 & 0.945 \\
\hline FLEX $(\mathrm{cm})$ & 18.09 & 14.54 & 10.40 & $0.003 *$ \\
\hline FFL $(\mathrm{N})$ & 241.00 & 227.44 & 1.00 & 0.325 \\
\hline IMTP $(\mathrm{N})$ & 900.30 & 829.16 & 3.85 & 0.059 \\
\hline $\mathrm{SJ}(\mathrm{cm})$ & 24.51 & 22.53 & 2.47 & 0.126 \\
\hline $\mathrm{CMJ}(\mathrm{cm})$ & 25.47 & 24.59 & 0.76 & 0.389 \\
\hline $5 \mathrm{M}(\mathrm{s})$ & 1.25 & 1.29 & 2.12 & 0.155 \\
\hline $10 \mathrm{M}(\mathrm{s})$ & 2.08 & 2.15 & 2.54 & 0.121 \\
\hline $30 \mathrm{M}(\mathrm{s})$ & 5.40 & 5.53 & 1.60 & 0.216 \\
\hline $\mathrm{TT}(\mathrm{s})$ & 12.57 & 13.09 & 1.72 & 0.199 \\
\hline HEX (s) & 14.16 & 16.50 & 8.04 & $0.008 *$ \\
\hline JAPT (s) & 9.68 & 9.95 & 0.98 & 0.331 \\
\hline $\mathrm{VO}_{2 \max }(\mathrm{ml} / \mathrm{min} / \mathrm{kg})$ & 32.41 & 31.93 & 5.74 & 0.023* \\
\hline Wilks Lambda & $\mathrm{F}^{1}$ & Effect - df & Error - df & $\mathrm{Q}$ \\
\hline 0.393 & 1.99 & 14 & 18 & 0.085 \\
\hline
\end{tabular}

Legend: Adjusted means - adjusted values of the arithmetic means; $\mathrm{F}^{2}$ - value of the F-test coefficient;

* - statistical significance; Wilks lambda - value of the Wilk's test coefficient for group centroid equality; $\mathrm{F}^{1}$ - value of the F-test coefficient for the significance of Wilk' lambda; Effect df; Error df - degrees of freedom; $\mathrm{Q}$ - centroid difference significance. 
Further analysis of Table 6 shows that there is no statistically significant difference between the groups of boys at the multivariate level. The experimental program of skill-based exercises had no greater effects on motor skills than the school physical education program among boys at the multivariate level, while at the univariate level, a statistically significant difference was observed in flexibility (FLEX: $\mathrm{F}=10.40, \mathrm{p}=0.003$ ), agility (HEX: $\mathrm{F}=8.04$, $\mathrm{p}=0.008)$ and cardiorespiratory fitness $\left(\mathrm{VO}_{2 \max }: \mathrm{F}=5.74, \mathrm{p}=0.023\right)$ where the boys of the experimental group achieved better results than those of the control group. It is evident that the boys from the experimental group made greater progress than the boys of the control group, while no statistical significance was observed in the other variables.

\section{Discussion}

In the experimental groups that participated in the specially designed program of skillbased exercises and small-sided games in volleyball in a third physical education class (elective PE class), girls achieved significantly better results on all the applied motor skills tests, while the boys also achieved significantly better results on all the tests except in the speed assessment test.

In the control groups of girls and boys who attended regular physical education classes, no significant differences were observed on any of motor skills tests.

After the univariate analysis of covariance with partialization of the results at the initial measurement, it was possible to determine the effectiveness of the applied experimental program of skill-based exercises and small-sided games. Based on the observed differences in Table 5, it can be concluded that the experimental program had a significant effect on the increase in flexibility, force, explosive strength, and agility in the experimental group of girls, while in the experimental group of boys the experimental program had a significant effect on the increase in flexibility, agility, and cardiorespiratory fitness (Table 6).

This outcome of the control group was expected, considering that many previous studies addressed the problems of character, quality, and intensification of physical education classes, indicating that current physical education is insufficiently oriented toward systematic and versatile physical exercise, and that it also lacks the appropriate volume and intensity that would cause stimuli that would improve the physical development and motor skills of elementary school children (Todorovski, 1994; Sallis et al., 1997; Stojanović, 1998; Branković, 2001; Milenković, 2002; Dragić, 2003; Koutedakis et al., 2003; Jurg et al., 2006; Pate et al., 2006; Stamatović et al., 2006). In a study by Đorđić et al. (2008), the authors draw attention to the negative trend of student physical activity, especially among the girls who are much less active than the boys from the fifth to the eighth grade.

The obtained results for the experimental groups are the effects of a specially designed program of skill-based exercises and small-sided games, implemented over a period of 16 weeks, with appropriate intensification of the elective physical education class, and as such proved to be much more effective than the school physical education curriculum. The basis of the application of skill-based exercises and small-sided games was found in earlier research by Gabbett (2008), where skill-based exercises and small-sided games have shown improvements in the vertical jump, volleyball spike jump, speed, agility, upper extremity muscle strength, as well as in maximal aerobic capacity of students aged 12, and volleyball players aged 15 (Hussein, 2012). In Trajković (2015), the author included skill-based volleyball exercises in the experimental program, which contributed to the development of explosive leg strength in adolescents. Another study conducted in Japan on a sample of 11.5-year-old students, Toyoda (2011) obtained similar results indicating that students who 
practiced mini-volleyball were superior in the vertical jump and back extensor strength compared to their peers.

The results obtained on the effectiveness of the implemented experimental program are in accordance with previous research which investigated the intensification of physical education classes by evaluating specially designed programs with volleyball and basketball content as part of the curriculum or as extracurricular activities. In a study by Ljubojević et al. (2011), basketball content has shown to have positive effects on the development of all the motor skills of boys on a smaller scale and of girls on a larger scale. In numerous studies (Bajrić et al., 2012; Korjenić et al., 2012; Šmigalović et al., 2012; Nešić et al., 2013), the authors applied content from volleyball and obtained results that showed positive effects on the development of basic motor skills and situational motor skills. Sozen (2012) managed to induce positive changes of agility and flexibility in girls by conducting volleyball training as an additional activity in physical education. In a study by Selmanović et al. (2013), participation in an experimental program, which included skill-based volleyball training exercises and mini volleyball as an additional activity for a period of nine months during regular physical education classes, showed positive changes in vertical jump height among fifth grade boys.

The achieved progress among the girls and boys of the experimental groups, in terms of motor skills, can be attributed to the applied experimental treatment, but it should be taken into consideration that the study sample included adolescents where growth and development surges occur, especially for certain motor skills. An accelerated occurrence rate is characteristic of "sensitive periods", in which specific effects provoke an increased reaction of the body, especially in "critical periods" which are part (a phase) of the sensitive period in which stimulation must occur if we want to achieve targeted developmental effects (Koprivica, 2002). Kamen (2001) states that the development of the motor skills of girls and boys is relatively uniform until the age of 12 or 13 , but some authors state that girls' maturation occurs earlier, thus the sensitive periods of development of some motor skills occur earlier than they do among boys, because girls enter puberty earlier (Koprivica, 2002; Malina, 2004). Before puberty begins, focus should be on the development of certain motor skills as girls mature earlier, enter and exit puberty earlier, and reach a definitive body height and performance plateau in some motor skills (Koprivica, 2002).

Based on the mentioned facts about the sensitive periods of motor development, it can be concluded that the results of this research, where the participants were in the "sensitive" stage of development, are in agreement with the fact that the period of middle school age (11-15 years) is a period in which there are optimal conditions for the development of flexibility, static force, explosive strength, agility, and cardiorespiratory fitness (Koprivica, 2002). The experimental program with its content of skill-based exercises and small-sided games (mini volleyball) caused changes in the development of these motor skills in accordance with the sensitive and critical periods, when the most optimal conditions for the motor quality establishment of students with a chronological age of $13 \pm 6$ years are present. For these reasons, it is very important to monitor sensitive periods for the development of targeted motor skills in a targeted population when it comes to planning and programming physical education classes to meet the needs of students, as well as their motor and bio-psycho-sociological development.

From the results of this research, it can be concluded that the experimental program of skillbased exercises, designed to increase the intensity of the elective physical education class (volleyball), contributed to a significant increase in the motor skills of the experimental groups of students. By comparing the effects of such a program and the current physical education curriculum, information was obtained that clearly indicates the greater effectiveness and superiority of the experimental program. 


\section{References}

Adam, C., Klissouras, V., Ravazzolo, M., Renson, R., \& Tuxworth, W. (1988). Eurofit: European Test of Physical Fitness. Rome: Council of European Committee for Development of Sport.

Bajrić, O., Šmigalović, M., Bašinac, I., \& Bajrić, S. (2012). Globalne kvantitativne promjene bazičnih i situaciono-motoričkih sposobnosti pod uticajem programa odbojke. Sportske nauke $i$ zdravlje, 3 (1), 22-28. doi:10.7251/ssh1201022b

Branković, N. (2001). Razvojne karakteristike motoričkih sposobnosti učenica na kraju šestomesečnog izvođenja nastave fizičkog vaspitanja. U S. Vučković (Ur.). Zbornik radova "Fis-komunikacije" (str. 205-207). Niš: Fakultet fizičke kulture.

Đorđić, V., \& Matić, R. (2008). Age and gender as factors of influence on the physical activity of children and adolescents. In G. Bala (Ed.), Anthropological status and physical activity of children and youth (pp. 55-77). Novi Sad: Faculty of Sport and Physical Education.

Dragić, B. (2003). Efekti alternativnog nastavnog plana i programa fizičkog vaspitanja na morfološke karakteristike, motoričke sposobnosti i socijalne karakteristike učenika VI razreda osnovne škole. Doktorska disertacija, Niš: Fakultet fizičke kulture.

Ferguson, C.J. (2009). An Effect Size Primer: A Guide for Clinicians and Researchers. Professional Psychology: Research and Practice, 40 (5), 532-538. doi:10.1037/a0015808

Gabbett, T.J. (2002). Training injuries in rugby league: an evaluation of skill-based conditioning games. Journal of Strength and Conditioning Research, 16, 236-241. doi:10.1519/00124278200205000-00011

Gabbett, T.J. (2008). Do skill-based conditioning games offer a specific training stimulus for junior elite volleyball players? Journal of Strength and Conditioning Research, 22, 509-517. doi:10.1519/jsc.0b013e3181634550

Grgantov, Z. (2003). Kondicijska priprema u odbojci. U D. Milanović i I. Jukić (Ur.), Zbornik radova, Međunarodni znanstveno-stručni skup "Kondicijska priprema sportaša", (str. 460-465). 21. - 22. veljače, Zagreb: Kineziološki fakultet.

Hardman, K. (2007). Current situation and prospects for physical education in the European Unionstudy. Brussels: The European Parliament's committee on Culture and Education.

Hussein, A.J., \& Alhayek, S.K. (2012). The Effect of Using Micro-Games of Volleyball in Improving Some Life, Movement, and Performance Skills for Sixth Grade Students. Journal of Educational and Psychological Sciences, 13 (4), 41-65.

Jurg, E.M., Kremers, P.J.S., Candel, J.J.M.M., van der Wall, F.M., \& de Meij, S.B.J. (2006). A controlled trial of a school-based enviromental Intervention to improve physical activity in Dutch Children: JUMP-in, kids in motion. Health Promotion International, 21 (4), 320-330. doi:10.1093/heapro/dal032

Kamen, G. (Ed.). (2001). Foundations of exercise science. Lippincott Williams \& Wilkins.

Keppel, G. (1991). Design and analysis: A researcher's handbook (3rd ed.). Upper Saddle River,NJ: Prentice Hall.

Koprivica, V. (2002). Osnove sportskog treninga. Beograd: Fakultet sporta i fizičkog vaspitanja.

Korjenić, A. , Jeličić, M. , Basinac, I., \& Begović, D. (2012). Efekti programirane nastave odbojke na nivo motoričkih sposobnosti i usvojenost elemenata odbojkaške igre. Sportske nauke i zadravlje, 2 (2), 93-99. doi:10.7251/ssh1202093k

Koutedakis, Y., \& Bouziotas, C. (2003). National physical education curriculum: motor and cardiovascular health related fitness in Greek adolescents. British Journal of Sports Medicine, 37, 311-314. doi:10.1136/bjsm.37.4.311

Ljubojević, M. (2011). Efekti nastavnog predmeta - sport za sportiste (košarka) na morfološke karakteristike i motoričke sposobnosti učenika VIII razreda osnovne škole. Godišnjak Fakulteta sporta i fizičkog vaspitanja, 17, 57-71.

Malina, R.M. (2004). Secular trends in growth, maturation and physical performance: a review. The Annual Review of Anthropology, 67, 3-31.

Marelić, N., Janković, V., Rešetar, T., \& Marelić, S. (2000.) Učenje odbojke putem modificiranih igara. U M. Andrijašević (Ur.), Zbornik radova međunarodnog savjetovanja "Slobodno vrijeme $i$ igra” (str. 130-133). Zagreb: Fakultet za fizičku kulturu. 
Milenković, V. (2002). Efekti primene eksperimentalnog programa sa akcentom na sportsku gimnastiku na neke motoričke sposobnosti učenika sedmog razreda osnovne škole. U R. Popović (Ur.) Zbornik radova "Fis-komunikacije", (str. 291-300), Niš: Fakultet fizičke kulture.

Nešić, G., Ilić, D., Majstorović, N., Grbić, V., \& Osmankač, N. (2013). Uticaj treninga na opšte i specifične motoričke sposobnosti odbojkašica uzrasta 13-14 godina. SportLogia, 9 (2), 119-127. doi:10.5550/sgia.130902.se.007n

Pate, R.R., Davis, G.M., Robinson, N.T., Stone, J.E., Mckenzie, L.T., \& Young, S.J. (2006). Promoting physical activity in children and youth. Circulation, 114 (11), 1214-1224. doi:10.1161/circulationaha.106.177052

Sallis, F.J., Mckenzie, L.T., Alcaraz, E.J., Kolody, V., Faucette, N., \& Hovell, F.M. (1997). The effects of 2-year physical education program (SPARK) on physical activity and fitness in elementary school students: Sports, play and active recreation for kids. The American Journal of Public Health, 87 (8), 1328-1334. doi:10.2105/ajph.87.8.1328

Selmanović, A., Milanović, D., \& Čustonja, Z. (2013). Effects of an additional basketball and volleyball program on motor abilities of fifth grade elementary school students. Collegium antropologicum, 37 (2), 391-400.

Službeni glasnik RS - Prosvetni glasnik (2006). Pravilnik o nastavnom planu za drugi ciklus osnovnog obrazovanja i vaspitanja i nastavni program za peti razred osnovne škole. Ministarstvo Prosvete RS, broj 6/07, 3/11, 1/13, 4/13, Beograd.

Šmigalović, M., Bajrić, O., \& Lolić, D. (2012). Uticaj programa odbojke na bazične i situacionomotoričke sposobnosti učenika uzrasta od 13 do 14 godina. Sportske nauke i zdravlje, 2 (1), 3540. doi:10.7251/ssh1201029s

Sozen, H. (2012). The effect of volleyball training on the physical fitness of high school students. Procedia-Social and Behavioral Sciences, 46, 1455-1460. doi:10.1016/j.sbspro.2012.05.320

Stamatović, M., \& Šekeljić, G. (2006). Uticaj različitih koncepcija nastave fizičkog vaspitanja na motorički status učenika mlađeg školskog uzrasta. U G. Bala (Ur.) Antropološki status i fizička aktivnost dece i omladine, Zbornik radova, (str. 301-310), Novi Sad: Fakultet sporta i fizičkog vaspitanja.

Stojanović, T. (1998). Uticaj nastavnih sadržaja iz košarke na psihosomatski status učenika u nastavi fizičkog vaspitanja. Magistarski rad. Skopje: Fakultet fizičke kulture.

Todorovski, D. (1994). Doprinos dve različite varijante II faze časa fizičkog vaspitanja učenika u osnovnoj školi. Magistarski rad. Beograd: Fakultet fizičke kulture.

Toyoda, H. (2011). Volleyball for beginners. FIVB Coach Manual, 2 (1), 29-69.

Trajković, N. (2015). Uticaj situaciono kondicionog treninga na eksplozivnu snagu i preciznost kod odbojkaša. Doktorska disertacija. Niš: Fakultet sporta i fizičkog vaspitanja.

\title{
UTICAJ PROGRAMA SITUACIONIH VEŽBI NA MOTORIČKE SPOSOBNOSTI UČENIKA
}

\author{
Darko Stojanović, Zoran Momčilović, Tijana Stojanović, Toplica Stojanović
}

Sažetak. Osnovni cilj ovog eksperimentalnog istraživanja je da utvrdi uticaj programa situacionih vežbi
na motoričke sposobnosti učenika. U istraživanju je učestvovalo 90 ispitanika, prosečne
starosti 13 godina koji su slučajnim izborom podeljeni u dve grupe: eksperimentalna [E; $n=39$
(19 devojčica i 20 dečaka)] i kontrolna grupa [K; $n=51$ ( 24 devojčica i 27 dečaka)]. Kod svih
ispitanika su na inicijalnom i finalnom merenju testirane motoričke sposobnosti. Motoričke
sposobnosti su procenjivane primenom: 3 testa za procenu fleksibilnosti, 4 testa za procenu
sile i snage, 4 testa za procenu brzine i ubrzanja i agilnosti i jedanza procenu kardiorespi-
ratorne izdržljivosti. Nakon primene 16 -to nedeljnog programa situacionih vežbi iz odbojke,
svi parametri motoričkih sposobnosti statistički značajno su se povećali kod eksperimentalne
grupe (osim brzine kod dečaka). U eksperimentalnom periodu ispitanici kontrolne grupe nisu
zabeležili značajne promene u parametrima motoričkih sposobnosti. Rezultati ovog istraži- 
vanja pokazali su da nije bilo značajnijh razlika uticaja dvaju programa na motoričke sposobnosti na multivarijantnom nivou, ali da je na univarijantnom nivou uočeno da ispitanici eksperimentalne grupe nakon primene eksperimentalnog programa imaju bolje rezultate $u$ odnosu na ispitanike kontrolne grupe u testovima gipkosti i agilnosti, kod oba pola, kao i sile i snage kod devojčica, odnosno aerobne izdržljivosti kod dečaka. Dobijeni rezultati ukazuju da je program situacionih vežbi iz odbojke pogodan za razvoj gipkosti, sile i snage i agilnosti.

Ključne reči: motoričke sposobnosti, uticaj programa, situacione vežbe, igra na skraćenom prostoru, učenici. 